\title{
Efficient Direct Electron Transfer for a Highly Oriented PQQ-GDH Immobilized Electrode for Bioanode
}

\author{
Ayako Koto ${ }^{1}$, Saki Taniya ${ }^{2}$, Hiroaki Sakamoto ${ }^{1 *}$, Takenori Satomura ${ }^{2}$, Haruhiko Sakuraba ${ }^{3}$, Toshihisa Ohshima ${ }^{4}$ and Shin-ichiro Suye ${ }^{1,2}$ \\ ${ }^{1}$ Department of Frontier Fiber Technology and Science, Graduate School of Engineering, University of Fukui, Fukui, Japan \\ ${ }^{2}$ Department of Applied Chemistry and Biotechnology, Graduate School of Engineering, University of Fukui, Fukui, Japan \\ ${ }^{3}$ Department of Applied Biological Science, Faculty of Agriculture, Kagawa University, Kanagawa, Japan \\ ${ }^{4}$ Department of Biomedical Engineering, Faculty of Engineering, Osaka Institute of Technology, Osaka, Japan
}

\begin{abstract}
A bioanode with improved enzyme orientation was developed to achieve an efficient enzyme reaction and electron transfer on an electrode surface. A highly stable PQQ-dependent glucose dehydrogenase (PQQ-GDH) isolated from a hyper-thermophilic archaeon was employed as an electron conversion element. PQQ-GDH is expected to maintain battery properties and to have a long battery life. To immobilize the enzyme onto the electrode with appropriate orientation, we introduced a His-tag to the N-terminal of PQQ-GDH by a genetic technique and utilized the affinity bond between His-tag and $\mathrm{Cu}$ atoms. The catalytic current density in the presence of substrate was $18.6 \mu \mathrm{A} / \mathrm{cm}^{2}$ without a mediator. The current density of the oriented electrode was approximately 90 times higher than that of the non-oriented electrode. By immobilizing the enzyme with orientation, the accessibility between the enzyme and substrate for enzyme reaction increased because the active site of $P Q Q-G D H$ is located opposite the electrode. Because enzymes have different orientations at the surface of the non-orientated electrode, the efficiency of the electrode was lower than that of the high-orientation electrode. The results of the present study present a potentially promising finding for application to practical bioelectric devices, such as bio-fuel cells and biosensors.
\end{abstract}

Keywords: Bioanode; PQQ-GDH; Oriented immobilization; Direct electron transfer

\section{Introduction}

Bio-fuel cells catalyzed by enzymes are expected to provide next-generation energy supply sources for microelectronic devices because they are safe to use and are light in weight and can be easily miniaturized [1-4]. The principle of bio-fuel cells is based on the redox reaction between the enzyme and substrate. The substrates are prepared from biomass and include glucose, methanol, ethanol, and lactate. Previously, many researchers have developed enzymatic biofuel cells [5-13] that were shown to have current and power densities to some extent, but were limited by major issues including low output of the battery because of inefficient redox reaction on the electrode surface and lower active lifetime because of low stability of enzyme $[14,15]$. Therefore, it has been considered difficult to achieve a practical bio-fuel cell thus far.

In the present study, in order to overcome the above issues, the following two strategies were used.

The first strategy was to increase the orientation of the enzyme immobilized onto the electrode surface. Because electron-transfer between the enzyme and electrode, and enzyme reactivity on the electrode surface, depend on the orientation of enzyme [16-19], controlled and oriented immobilization of enzyme onto the electrode surface is required [20-25]. However, it is not easy to modulate macromolecules, e.g., enzymes and peptides, on the electrode surface. Because macromolecules have an intricate chemical and physical structure, the enzyme orientation on the electrode surface is the major rate-limiting factor for enzyme function. In the past, various approaches, such as covalent cross-linking [26,27], Layer-By-Layer (LBL) [28-30], and Self-Assembled Monolayers (SAM) [31-34], have been reported for the immobilization of macromolecules on solid substrates. Almost all of these techniques have been based on covalent cross-linking through chemical reactions that lack site selectivity. Using the above immobilization methods, specificity of the reaction site in the macromolecule cannot be obtained because the macromolecules have more than one reactive group on their surface.
The second approach is to employ PQQ-GDH obtained from the hyperthermophilic archaeon, Pyrobaculum aerophilum [35]. PQQ-GDH from hyperthermophiles, which can grow at or near the boiling point of water, is much more stable than that obtained from mesophilic microorganisms or eukaryotic organisms. In addition, PQQ-GDH can utilize artificial dyes such as 2,6-Dichloroindophenol (DCIP) and ferricyanide as electron acceptors. PQQ-GDH has high potential for utilization as a specific element for a bioanode electrode because electrons from $\mathrm{D}$-glucose can be introduced to the electrode using an artificial dye as the mediator. Use of PQQ-GDH from the hyperthermophilic archaeon provided a long cell life and high power output.

In the present study, we developed a bio-anode electrode by highly oriented immobilization of PQQ-GDH. To immobilize the enzyme with orientation, we employed the interaction between Histag (consisting of six successive histidine residues) and the $\mathrm{Cu}$ atom. As the His-tag acts as an immobilization site on the electrode surface, the enzyme can be immobilized with a high degree of orientation (Figure 1). We have introduced the His-tag into the PQQ-GDH from Pyrobaculum aerophilium by using a genetic technique. The PQQGDH-(His-tag) was immobilized onto a $\mathrm{Cu}$-deposited electrode with a high degree of orientation. The highly oriented immobilized PQQGDH electrodes were investigated using electrochemical techniques to obtain information on the properties of the constructed electrode.

*Corresponding author: Hiroaki Sakamoto, Department of Frontier Fiber Technology and Science, Graduate School of Engineering, University of Fukui, Fukui, Japan, Tel: 0776-27-9753; E-mail: hi-saka@u-fukui.ac.jp

Received January 29, 2014; Accepted March 27, 2014; Published April 02, 2014

Citation: Koto A, Taniya S, Sakamoto H, Satomura T, Sakuraba H, et al. (2014) Efficient Direct Electron Transfer for a Highly Oriented PQQ-GDH Immobilized Electrode for Bioanode. J Biosens Bioelectron 5: 148. doi: 10.4172/21556210.1000148

Copyright: (c) 2014 Koto A, et al. This is an open-access article distributed under the terms of the Creative Commons Attribution License, which permits unrestricted use, distribution, and reproduction in any medium, provided the original author and source are credited. 


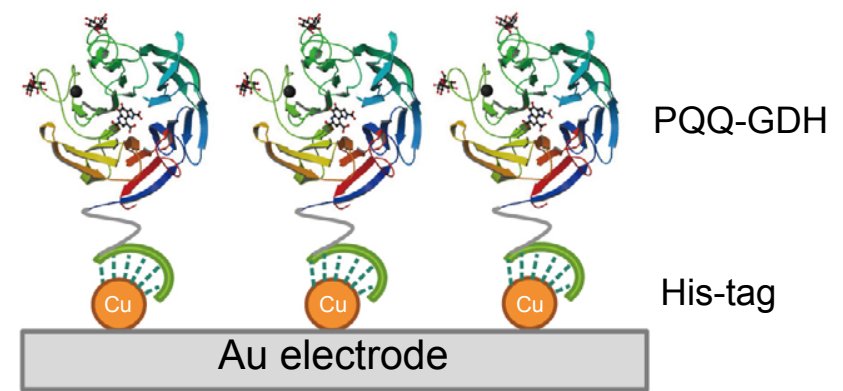

Figure 1: Schematic illustration of $P Q Q-G D H-(H i s-t a g)$ immobilization onto the $\mathrm{Cu}$ deposited electrode surface. Deposited $\mathrm{Cu}$ (orange spheres) and His-tag (green arcs) are forming affinity binding.

\section{Material and Methods}

\section{Chemicals}

$\mathrm{D}(+)$-Glucose, sodium chloride, copper(II) sulfate pentahydrate $\left(\mathrm{CuSO}_{4} \cdot 5 \mathrm{H}_{2} \mathrm{O}\right)$, nickel(II) sulfate hexahydrate $\left(\mathrm{NiSO}_{4} \cdot 6 \mathrm{H}_{2} \mathrm{O}\right)$, imidazole, 1-Ethyl-3-(3-Dimethylaminopropyl) Carbodiimide Hydrochloride (EDC) and Pyrroloquinoline quinone disodium salt (PQQ) were purchased from Wako Pure Chemical Industries, Ltd. (Osaka, Japan). Potassium chloride (KCl) and 2-[4-(2-Hydroxyethyl) piperazin-1-yl] ethanesulfonic acid (HEPES) were obtained from Nacalai Tesque. Inc. (Kyoto, Japan). 2-Morpholinoethanesulfonic acid, monohydrate (MES) was purchased from Dojindo Laboratories (Kumamoto, Japan). The water used in the present experiment was first deionized and passed through a Milli-Q water purification system from Millipore Co. (Bedford, MA, USA).

\section{Preparation of PQQ-GDH-(His-tag)}

To prepare purified PQQ-GDH-(His-tag) by nickel affinity chromatography, a six-His sequence was fused at the $\mathrm{N}$-terminal of the PQQ-GDH protein. The $\mathrm{pET} 15 \mathrm{~b} / \mathrm{PaeAsd}$ plasmid encoding PQQ-GDH was used as the PQQ-GDH-(His-tag) expression vector. The expression vector of the PQQ-GDH-(His-tag) fusion protein was constructed as follows. The coding region of the PQQ-GDH gene was obtained by digesting pET/PaeAsd with NdeI/BamHI [36], and then the fragment was ligated with the expression vector $\mathrm{pET} 15 \mathrm{~b}$ (Novagen, Merck Millipore Japan (Tokyo, Japan)), which had been linearized with NdeI and BamHI. The pET15/PaeAsd plasmid was verified by DNA sequencing.

PQQ-GDH-(His-tag) was expressed in Escherichia coli BL21CodonPlus(DE3)-RIL grown in LB medium containing ampicillin. Recombinant PQQ-GDH-(His-tag) proteins were induced by adding $1 \mathrm{mM}$ isopropyl- $\beta$-D-thiogalacto-pyranoside at $\mathrm{OD}_{600} 0.6$, and cultivation was continued for an additional $4 \mathrm{~h}$. Cells were harvested by centrifugation at $10,000 \times \mathrm{g}$, suspended in lysis buffer $(20$ $\mathrm{mM}$ HEPES ( $\mathrm{pH}$ 7.5), $100 \mathrm{mM} \mathrm{NaCl}, 1 \mathrm{mM} \mathrm{CaCl}_{2}$ ), and disrupted by ultrasonication. The cell debris was removed by centrifugation $(12,000 \times \mathrm{g}$ for $10 \mathrm{~min})$ and the supernatant solution was used as the crude extract. The enzyme solution was incubated at $80^{\circ} \mathrm{C}$ for $10 \mathrm{~min}$. Denatured proteins were separated by centrifugation $(12,000 \times \mathrm{g}$ for 10 $\mathrm{min})$.The resultant supernatant was used for further purification. To reconstitute the apoenzyme with PQQ, a 10-fold molar excess of PQQ was added into the enzyme solution and incubated it for $16 \mathrm{~h}$ at $4^{\circ} \mathrm{C}$.

To obtain purified PQQ-GDH-(His-tag), the holoenzyme, after reconstitution of the apoenzyme with $\mathrm{PQQ}$, was purified by using $\mathrm{Ni}$ -
NTA chromatography (HisTrap HP column; GE Healthcare UK Ltd, Little Chalfont, Bucks, UK). The enzyme was loaded onto the column equilibrated with $20 \mathrm{mM}$ potassium phosphate buffer at $\mathrm{pH} 7.5$ and eluted from the column using an elution buffer $(300 \mathrm{mM} \mathrm{NaCl}, 500$ $\mathrm{mM}$ imidazole, $20 \mathrm{mM}$ potassium phosphate buffer, at $\mathrm{pH}$ 7.0). The purified PQQ-GDH-(His-tag) proteins were dialyzed to remove imidazole and replace the buffer (50 mM HEPES pH 7.5), and stored at room temperature until further use.

The activity of PQQ-GDH-(His-tag) was measured using 2,6-Dichlorophenolindophenol (DCIP) as described previously [37]

\section{Electrochemical experiments}

Cyclic Voltammetry (CV) was conducted using a three-electrode cell at $50^{\circ} \mathrm{C}$ on an ALS electrochemical analyzer (BAS Inc., Tokyo, Japan). The working electrode was gold (geometrical area: $0.02 \mathrm{~cm}^{2}$, BAS Inc.), the counter electrode was a platinum wire, and the reference electrode was $\mathrm{Ag} / \mathrm{AgCl}$. All potential values below are reported with respect to the $\mathrm{Ag} / \mathrm{AgCl}$ reference electrode. The electrolyte solution was $50 \mathrm{mM}$ HEPES buffer at $\mathrm{pH}$ 7.5. The $\mathrm{CV}$ measurements were recorded at a potential scan rate of $0.01 \mathrm{~V} / \mathrm{s}$. The working electrode was sonicated in $50 \mathrm{mM} \mathrm{H}_{2} \mathrm{SO}_{4}$, and then the surface was polished with a micro-cloth and alumina slurry suspension $(\varphi=0.1 \mu \mathrm{m})$. The electrode was scanned 50 times at a potential scan rate of $0.1 \mathrm{~V} / \mathrm{s}$, at potentials ranging from $-1.0 \mathrm{~V}$ to $1.0 \mathrm{~V}$. Finally, the electrode was sonicated in Milli-Q water.

\section{Electrode modification}

$\mathrm{Au} / \mathrm{Cu} / \mathrm{PQQ}-\mathrm{GDH}-(\mathrm{His}-\mathrm{tag}): \mathrm{CuSO}_{4}$ was dissolved in $100 \mathrm{mM}$ sodium chloride to a final concentration of $100 \mathrm{mM}$. Copper deposition was controlled by applying a potential of $-0.3 \mathrm{~V}$ vs. $\mathrm{Ag} / \mathrm{AgCl}$ to the $\mathrm{Au}$ electrode for $5 \mathrm{~min}$. Then, the electrode was rinsed with Milli-Q water and immersed in $0.98 \mathrm{mg} / \mathrm{ml}$ PQQ-GDH-(His-tag) solution (at room temperature, $5 \mathrm{~min}$ ) to immobilize the PQQ-GDH-(His-tag). The electrode was rinsed again with 50mM HEPES buffer at $\mathrm{pH}$ 7.5.

C/ PQQ-GDH-(His-tag): The freshly polished carbon electrode $\left(0.07 \mathrm{~cm}^{2}\right)$ was immersed in $100 \mathrm{mM} \mathrm{H}_{2} \mathrm{SO}_{4}$ for $1 \mathrm{~h}$, washed, and electrolytically oxidized at $+1.2 \mathrm{~V}$ in $5 \% \mathrm{~K}_{2} \mathrm{Cr}_{2} \mathrm{O}_{7}$ in $10 \% \mathrm{HNO}_{3}$ to introduce carboxyl groups on the electrode surface. The electrode was immersed in freshly prepared $400 \mathrm{mM}$ EDC solution in $10 \mathrm{mM} \mathrm{MES}$ buffer at $\mathrm{pH} 4.5$ for $1 \mathrm{~h}$, and then immersed in $0.98 \mathrm{mg} / \mathrm{ml}$ enzyme solution overnight at room temperature.

\section{Estimation of electrode area}

$\mathrm{CV}$ was conducted with the $\mathrm{Au} / \mathrm{Cu}$ electrode and the carbon electrode in the $25 \mathrm{mM}$ potassium ferricyanide $/ 25 \mathrm{mM}$ potassium ferrocyanide solution. Potassium ferrocyanide and potassium ferricyanide react as shown in Eq. (1). The peak reflecting the number of molecules that have reacted at the electrode surface obtained from $\mathrm{CV}$ and the electrode area (A) was calculated using the peak and Eq. (2). Ip is the peak current, $\mathrm{n}$ is the number of electrons, $\mathrm{DR}$ is the diffusion coefficient, $v$ is the scan rate, and $\mathrm{C}$ is the concentration.

$$
\begin{aligned}
& {\left[\mathrm{Fe}(\mathrm{CN})_{6}\right]^{4-} \rightleftharpoons\left[\mathrm{Fe}(\mathrm{CN})_{6}\right]^{3-}+e^{-}} \\
& A=\frac{i_{p}}{269 \eta^{3 / 2} D_{R}^{1 / 2} C R^{\star} v^{1 / 2}}
\end{aligned}
$$

\section{Quantification of the immobilized enzyme}

To remove the enzyme from electrode surface, the $\mathrm{Au} / \mathrm{Cu} / \mathrm{PQQ}-$ 
GDH-(His-tag) electrode was immersed in the $500 \mathrm{mM}$ imidazole solution $(0.2 \mathrm{ml})$ for $30 \mathrm{~min}$ at room temperature. Quantification was performed using this solution. We determined the amount of immobilized His-PQQGDH using a protein quantification kit (Invitrogen ${ }^{\mathrm{TM}}$ CBQCA Protein Quantitation Kit (C-6667); Life Technologies Co., Carlsbad, CA, USA) and followed the kit instructions. Bovine serum albumin was used as the standard protein.

\section{Results and Discussion}

\section{Long-term Stability of PQQ-GDH-(His-tag)}

It is known that PQQ-GDH-(His-tag) from the hyperthermophilic archaeon $P$. aerophilum is much more stable than PQQ-GDH from mesophilic organisms under a variety of conditions such as a wide range of $\mathrm{pH}$ values and temperatures [38]. For this enzyme, smaller overall volumes have been shown to contribute to greater protein thermostability. Aromatic interactions are also known to participate in the stabilization of enzyme structures. When used as an electrode for a bio-fuel cell, long-term stability is also an important property. Assuming storage at room temperature, we examined the longterm stability of the enzyme. The PQQ-GDH-(His-tag) solution was stored at room temperature, and the activity was measured every few days. Enzyme activity was measured using DCIP, and even after approximately one month, the enzymatic activity of PQQ-GDH-(Histag) was maintained at more than $90 \%$ (Figure 2).

\section{Electrocatalytic reaction of immobilized PQQ-GDH-(His-} tag)

PQQ-GDH-(His-tag) catalyzes the oxidation of D-glucose. Direct Electron Transfer (DET) is achieved by passing of electrons produced by oxidation of D-glucose to the electrode through the PQQ existing inside the enzyme. To immobilize the enzyme with orientation, the affinity between the His-tag and deposited $\mathrm{Cu}$ atoms was utilized. The His-tag domain is widely used for protein purification and for molecular immobilization using nickel-nitrilotriacetic acid (Ni-NTA) $[39,40]$ because it can form a complex with transition metal ions. It was recently reported that not only transition metal ions, such as $\mathrm{Ni}^{2+}$, $\mathrm{Co}^{2+}, \mathrm{Cu}^{2+}, \mathrm{Zn}^{2+}$, but also zero-valent metals can form complexes [41]. Using this reaction, we can immobilize enzymes with a high degree

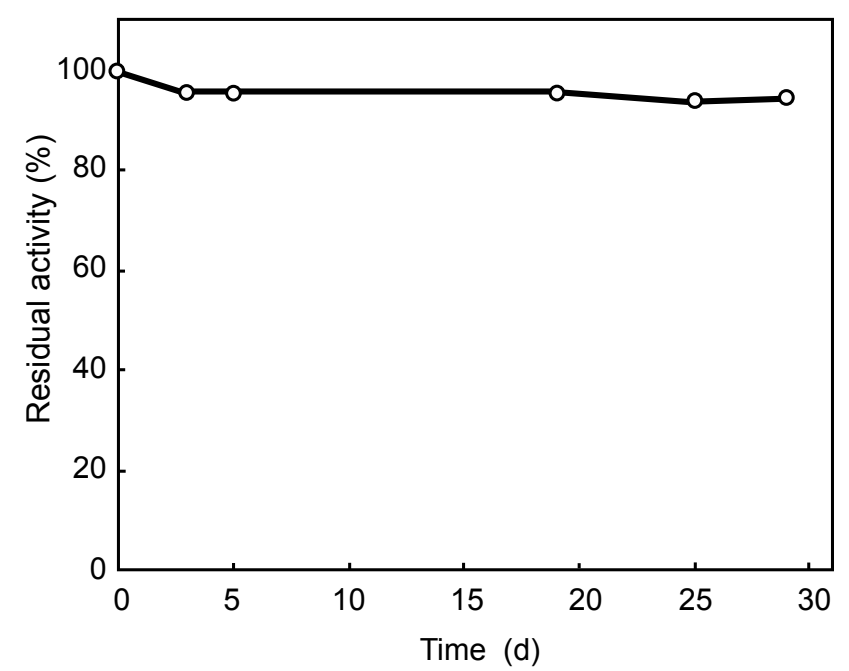

Figure 2: Long-term stability of $P Q Q-G D H-(H i s-t a g)$ from hyperthermophilicarchaeon $(n=3)$. Residual activity of the PQQ-GDH-(His-tag) (open circles) was measured after storage at room temperature.

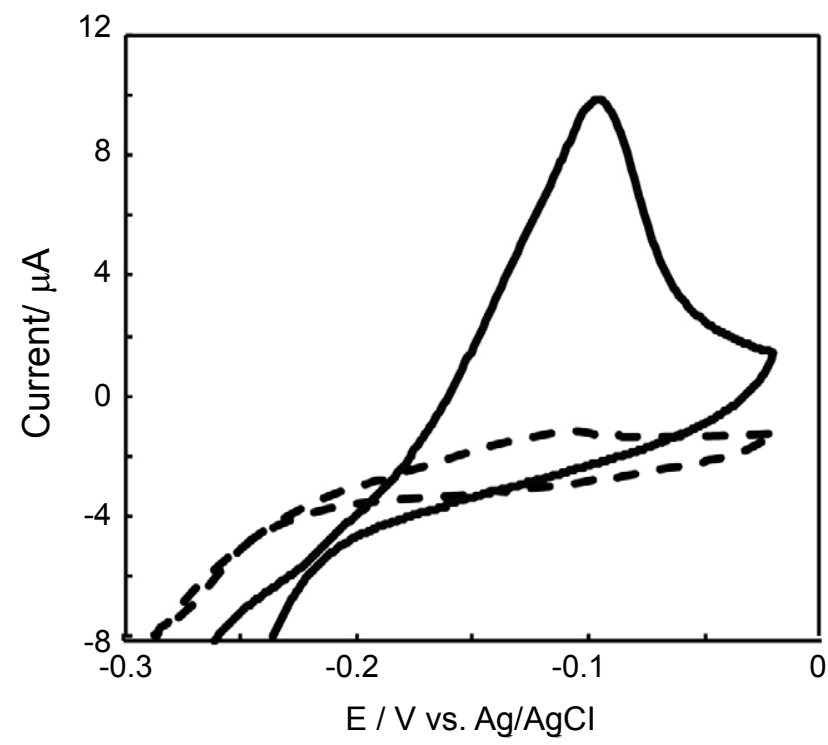

Figure 3: Typical cyclic voltammogram of the Au/Cu/ PQQ-GDH-(His-tag) electrode in the absence (dotted-line) and presence of $5 \mathrm{mM} \mathrm{D}(+)$-Glucose (solid line) in $50 \mathrm{mM}$ HEPES- $\mathrm{NaOH}$ buffer $(\mathrm{pH} \mathrm{7.5})$ at a scan rate of $0.01 \mathrm{~V} / \mathrm{s}$.

of orientation via a His-tag, without requiring modification involving NTA. Therefore, we prepared the PQQ-GDH-(His-tag) modified electrode on the deposited $\mathrm{Cu}$ electrode $(\mathrm{Au} / \mathrm{Cu} / \mathrm{PQQ}-\mathrm{GDH}-(\mathrm{His}-$ tag)). Figure 3 shows the $\mathrm{CV}$ of the catalytic reaction of the $\mathrm{Au} / \mathrm{Cu} /$ PQQ-GDH-(His-tag) electrode. Because deposited $\mathrm{Cu}$ atoms are not oxidized at less than $0 \mathrm{~V}, \mathrm{CV}$ was performed from $-0.3 \mathrm{~V}$ to $0 \mathrm{~V}$. When using the $\mathrm{Au} / \mathrm{Cu} / \mathrm{PQQ}-\mathrm{GDH}$-(His-tag) in the absence of substrate, a small peak was observed at $-0.11 \mathrm{~V}$, which represents oxidation of PQQ in the enzyme by DET, which confirmed DET between the enzyme and electrode, as previously reported [36-38]. When $5 \mathrm{mM}$ D-glucose existed in the electrolyte solution, the catalytic current arising from the oxidation reaction catalyzed by PQQ-GDH-(His-tag) was observed in the vicinity of $-0.1 \mathrm{~V}$ vs. $\mathrm{Ag} / \mathrm{AgCl}$. When PQQ was not incorporated in the GDH and enzymes were not immobilized on the electrode, a similar peak was not observed, even after addition of $\mathrm{D}$-glucose. These findings prove that a catalytic oxidation current was obtained from the reaction of immobilized enzymes on the $\mathrm{Au} / \mathrm{Cu}$ electrode.

\section{Confirmation of highly oriented immobilization}

We have confirmed that the PQQ-GDH-(His-tag) is immobilized to the $\mathrm{Au} / \mathrm{Cu}$ electrode via the His-tag. His-tag is a short peptide chain consisting of six histidine residues that coordinates to the transition metal by sharing the electron density of the nitrogen of the imidazole ring of histidine in the His-tag. Upon imidazole treatment, imidazole molecules act antagonistically to the imidazole ring of histidine residues of His-tag; then, the His-tag leaves the $\mathrm{Cu}$, and the protein is removed from the electrode surface. In the $\mathrm{CV}$ measurements using electrodes treated with imidazole, the peak value of the catalytic current of oxidation of D-glucose was dramatically decreased (Figure 4). With an increase in the concentration of imidazole, reduction of the peak value was also observed. Because PQQ-GDH-(His-tag) is definitely eliminated by imidazole treatment, the enzyme definitely binds to the electrode via $\mathrm{Cu}$ atoms. Therefore, the immobilized enzymes may achieve a high degree of orientation on the electrode. 


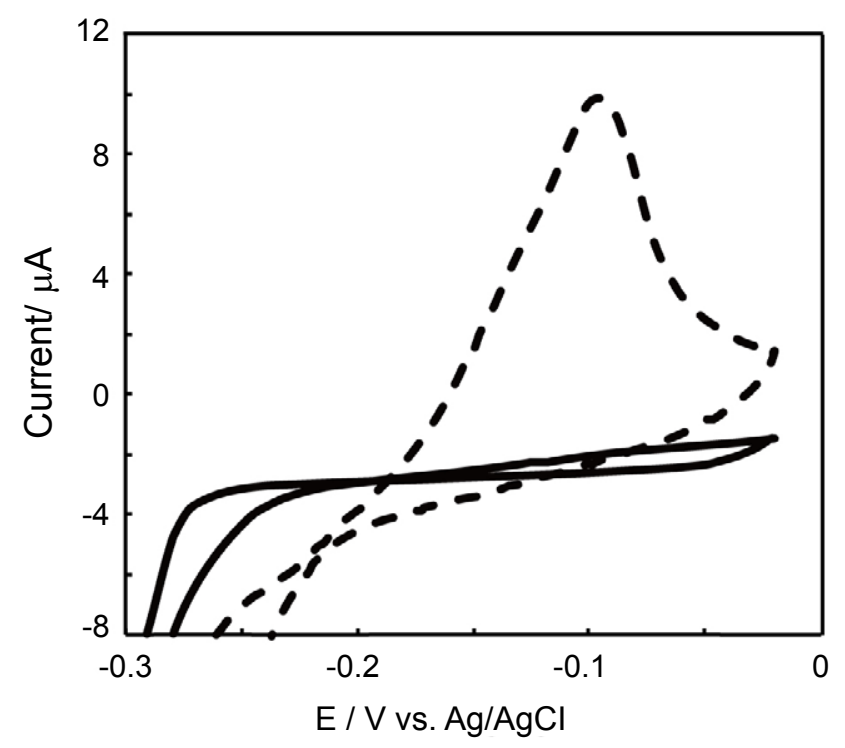

Figure 4: Typical cyclic voltammogram of $\mathrm{PQQ}-\mathrm{GDH}-(\mathrm{His}-\mathrm{tag}) / \mathrm{Cu} / \mathrm{Au}$ electrode in the presence of $5 \mathrm{mM} \mathrm{D}(+)$-Glucose without treatment involving imidazole solution (dotted-line) and with treatment involving imidazole solution (solid line), in $50 \mathrm{mM}$ HEPES-NaOH buffer $(\mathrm{pH} 7.5)$ at a scan rate of $0.01 \mathrm{~V} / \mathrm{s}$.

\section{Effect of the high degree of orientation of the enzyme}

We compared the efficiency of a highly oriented electrode containing a His-tag (Au/Cu/PQQ-GDH-(His-tag)) and a nonoriented electrode functionalized by EDC (C/PQQ-GDH-(His-tag)). To evaluate the efficiency of enzyme reaction on the electrode surface, the properties of the electrode (electrode area and total amount of electroactive coverage on electrodes) were analyzed.

The electrode area of the $\mathrm{Cu}$-deposited $\mathrm{Au}$ electrode $(\mathrm{Au} / \mathrm{Cu})$ was determined using the electrode reaction of potassium ferricyanide. The value of $-0.925 \mathrm{~mA}$ was obtained for the reduction peak; thus, the electrode area was estimated to be $0.40 \mathrm{~cm}^{2}$ by using equation (2). Before deposition, the geometric area of the Au electrode was $0.02 \mathrm{~cm}^{2}$, so the electrode area was increased by 20 -fold compared with the bare Au electrode.

To determine the total amount of immobilized enzyme on the electrode, we modified gold electrodes as described above and then washed off the His-tagged enzymes by immersing the electrode in an imidazole solution. After washing, the total amount of protein in the imidazole solution was measured. The protein concentration was determined according to the BSA calibration curve. PQQ-GDH(His-tag) attached to the modified gold electrode with a density of $5.25 \times 10^{-11} \mathrm{~mol} / \mathrm{cm}^{2}$. However, it was not possible to determine the amount of immobilized enzyme on the randomly oriented electrode because of the lack of an effective method.

CV was also used to study the DET electrochemistry of PQQ$\mathrm{GDH}$-(His-tag) immobilized on the $\mathrm{Au} / \mathrm{Cu}$ electrodes. PQQ-GDH(His-tag) shows DET properties derived from the redox of PQQ in CV measurements (Figure 3). In this study, the His-Cu affinity bond and EDC amide bond were used for enzyme modification on the $\mathrm{Au} / \mathrm{Cu} /$ PQQ-GDH-(His-tag) electrode and C/PQQ-GDH-(His-tag) electrode, and electroactive coverage of each electrode was estimated from the oxidation peak current of PQQ $\left(\mathrm{Ip}_{\mathrm{PQQ}}\right)$. The peak current for an electrode-immobilized reactant is given by Eq. (3).

$$
I p=\frac{n^{2} F^{2}}{4 R} A \Gamma v
$$

where $\mathrm{n}$ is the number of electrons transferred (2), $\mathrm{F}$ is the Faraday constant, $\mathrm{R}$ is the universal gas constant, $\mathrm{T}$ is the absolute temperature in Kelvin $(313.15 \mathrm{~K}), \mathrm{A}$ is the surface area of the electrode, $\Gamma$ is the surface coverage, and $v$ is scan rate $(0.01 \mathrm{~V} / \mathrm{s})$. From $\operatorname{Ip}_{\mathrm{PQQ}}(0.73 \times$ $10^{-6} \mathrm{~A}$ (Figure 4 gray line)), the estimated number of molecules of the electroactive enzyme immobilized on the electrode surface $\left(\Gamma_{\mathrm{PQQ}}\right)$ was $5.10 \times 10^{-11} \mathrm{~mol} / \mathrm{cm}^{2}$ for the $\mathrm{Au} / \mathrm{Cu} / \mathrm{PQQ}-\mathrm{GDH}$-(His-tag) electrode prepared via the His-Cu affinity bond. In conjunction with the above results, it was therefore suggested that $97 \%$ of the total immobilized enzyme molecules were maintained in an electroactive state. Similarly, from $\operatorname{Ip}_{\mathrm{PQQ}}\left(0.15 \times 10^{-6} \mathrm{~A}(\mathrm{CV}\right.$ data not shown $\left.)\right), 4.19 \times 10^{-11} \mathrm{~mol} / \mathrm{cm}^{2}$ enzyme molecules were electroactive on the C/PQQ-GDH-(His-tag) electrode prepared via amide bonding.

Electrochemical properties of the highly oriented electrode containing the His-tag and the non-orientated electrode obtained using a cross-linking reaction were compared. The results are shown in Table 1. Although the orientation of each electrode was different, the $\Gamma_{\mathrm{PQQ}}$ values were very similar between the two electrodes. There were few differences between the electrodes regarding electron transfer. According to the three-dimensional structure of PQQ-GDH [35], the attached PQQ was in the center of the enzyme; therefore, it is considered that the distance between PQQ and the electrode was almost identical (Figure 5a). Thus, in the case of DET of PQQ, the orientation of the enzyme did not affect the efficiency of electrochemical reaction.

The electroactive coverage on each electrode surface was calculated from the oxidization of PQQ and approximately the same for both electrodes. However, the current density (the current of PQQ was subtracted) of each electrode was quite different: $18.6 \mu \mathrm{A}$ for the highly oriented electrode, and $0.20 \mu \mathrm{A}$ for the non-oriented electrode. Therefore, it was shown that the highly orientated electrode was more efficient than the non-oriented electrode. In the highly orientated electrode, PQQ-GDH-(His-tag) is immobilized to $\mathrm{Cu}$ by a His-tag attached to the $\mathrm{N}$-terminal of the enzyme. It is expected that the catalytic reaction is facilitated because accessibility of the substrate is not blocked, as the active site of the enzyme is located opposite to the electrode surface (Figure 5b). Because the enzyme molecules had different orientations on the non-oriented electrode surface, the efficiency was lower than that of the highly oriented electrode. These results demonstrated in this study will allow high-performance bio-fuel cells to be designed and constructed, and lead to practical usage.

\section{Conclusion}

In the present study, we developed an anode to realize a highly efficient reaction by focusing on affinity binding between $\mathrm{Cu}$ and Histag. In the study of electrodes for bio-fuel cell, the stability of the enzyme itself is a major challenge, but enzymes from hyperthermophiles can solve this problem because they have high thermostability and longterm stability. In the PQQ-GDH used in this study, PQQ is present

\begin{tabular}{|l|c|c|c|}
\hline Electrode & $\begin{array}{c}\text { Current Density } \\
\left(\boldsymbol{\mu A} / \mathbf{c m}^{2}\right)\end{array}$ & $I_{\mathrm{PQQ}}(\boldsymbol{\mu A})$ & $\begin{array}{c}\text { Electroactive } \\
\text { molecules }\left(\mathbf{m o l} / \mathbf{c m}^{2}\right)\end{array}$ \\
\hline $\begin{array}{l}\text { Random } \\
\text { Immobilization }\end{array}$ & 0.20 & 0.15 & $4.19 \times 10^{-11}$ \\
\hline $\begin{array}{l}\text { (Covalent Bond) } \\
\text { High-oriented } \\
\text { Immobilization }\end{array}$ & 18.6 & 0.73 & $5.10 \times 10^{-11}$ \\
\hline (His-tag affinity) & 18 & \\
\hline
\end{tabular}

Table 1: Comparison of electrochemical properties in each electrode system. 
Citation: Koto A, Taniya S, Sakamoto H, Satomura T, Sakuraba H, et al. (2014) Efficient Direct Electron Transfer for a Highly Oriented PQQ-GDH Immobilized Electrode for Bioanode. J Biosens Bioelectron 5: 148. doi: 10.4172/2155-6210.1000148
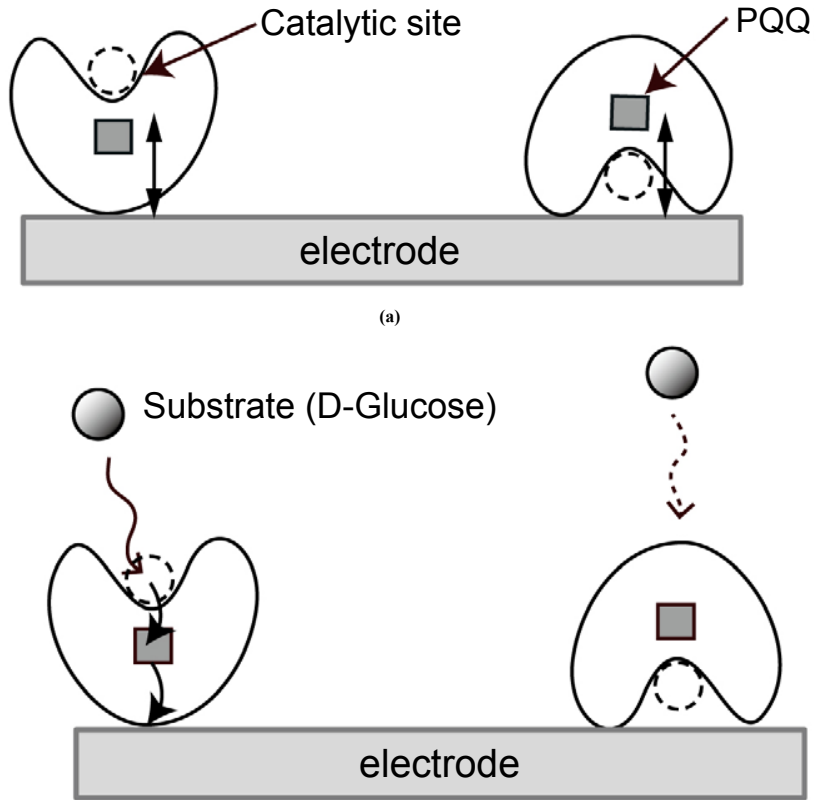

Oriented Immobilization (His-tag)

Random Immobilization

(Covalent bond)

(b)

Figure 5: Schematic illustration of electron-transfer process on the highly oriented or randomly oriented enzyme layer between PQQ-GDH and electrode (a) Direct electron transfer of $\mathrm{PQQ}$ (b) Electrochemical catalytic reaction. Orientation of the enzyme does not affect the electron transfer through the PQQ (a). However, the enzymatic reaction is inhibited if the catalytic site was located on the electrode surface (b).

inside the enzyme, and electron transfer is performed through the PQQ to provide a current density of $18.6 \mu \mathrm{A} / \mathrm{cm}^{2}$ without mediators. We determined the amount of enzyme that existing on the surface of the electrode, and showed that a highly efficient electrode reaction was achieved by orientation of the enzymes. The His-Cu affinity bond allowed proper orientation of the active site, thereby permitting an effective electrode reaction. By employing His-PQQGDH from the hyperthermophilic archaeon $P$. aerophilum with a high degree of orientation, it may become possible to develop a practical bioanode with long-term stability.

\section{Acknowledgment}

This work was supported by the Japan Society for the Promotion of Science (JSPS) KAKENHI (23510127) Grant-in-Aid for Scientific Research (C).

\section{References}

1. Himmel ME, Ding SY, Johnson DK, Adney WS, Nimlos MR, et al. (2007) Biomass recalcitrance: Engineering plants and enzymes for biofuels production. Science 315: 804-807.

2. Rabaey K, Verstraete W (2005) Microbial fuel cells: novel biotechnology for energy generation. Trends Biotechnol 23: 291-298.

3. Barton SC, Gallaway J, Atanassov P (2004) Enzymatic biofuel cells for implantable and microscale devices. Chem Rev 104: 4867-4886.

4. Rabaey K, Boon N, Siciliano SD, Verhaege M, Verstraete W (2004) Biofue cells select for microbial consortia that self-mediate electron transfer. Appl Environ Microbiol 70: 5373-5382.

5. Karra S, Zhang M, Gorski W (2013) Electrochemistry and current control in surface films based on silica-azure redox nanoparticles, carbon nanotubes, enzymes, and polyelectrolytes. Anal Chem 85: 1208-1214.
6. Yehezkeli O, Tel-Vered R, Raichlin S, Willner I (2011) Nano-engineered flavindependent glucose dehydrogenase/gold nanoparticle-modified electrodes for glucose sensing and biofuel cell applications. ACS Nano 5: 2385-2391.

7. Rengaraj S, Kavanagh P, Leech D (2011) A comparison of redox polymer and enzyme co-immobilization on carbon electrodes to provide membraneless glucose/O2 enzymatic fuel cells with improved power output and stability Biosens Bio 30: 294-299.

8. Tanne C, Göbel G, Lisdat F (2010) Development of a (PQQ)-GDH-anode based on MWCNT-modified gold and its application in a glucose/O2-biofue cell. Biosens Bioelectron 26: 530-535

9. Zhang J, Zhu Y, Chen C, Yang X, Li C (2012) Carbon nanotubes coated with platinum nanoparticles as anode of biofuel cell. Particuology 10: 450-455.

10. Salen FS, Mao L, Ohsaka T (2011) Development of a dehydrogenase-based glucose anode using a molecular assembly composed of nile blue and functionalized SWCNTs and its applications to a glucose sensor and glucose/ O2 biofuel cell. Sens Actuat Chem 152:130-135

11. Liu X, Luo L, Ding Y, Ye D (2011) Poly-glutamic acid modified carbon nanotube-doped carbon paste electrode for sensitive detection of L-tryptophan Bioelectrochemistry 82: 38-45.

12. Poulpiquet AD, Ciaccafava A, Lojou $E$ (2013) New trends in enzyme immobilization at nanostructured interfaces for efficient electro-catalysis in biofuel cells. Electr Act in press.

13. Pita M, Sanchez CG, Olea D, Velez M, Diego CG, et al. (2011) High redox potential cathode based on laccase covalently attached to gold electrode. J Phys Chem C 115: 13420-13428.

14. Davis F, Higson SP (2007) Biofuel cells--recent advances and applications Biosens Bioelectron 22: 1224-1235.

15. Kim J, Jia H, Wang $P$ (2006) Challenges in biocatalysis for enzyme-based biofuel cells. Biotechnol Adv 24: 296-308.

16. Zafer MN, Wang X, Sygmund C, Ludwig R, Leech D, et al. (2012) Electrontransfer studies with a new flavin adenine dinucleotide dependent glucose dehydrogenase and osmium polymers of different redox potentials. Anal Chem 84: 334-341.

17. Okuda J1, Wakai J, Yuhashi N, Sode K (2003) Glucose enzyme electrode using cytochrome $b(562)$ as an electron mediator. Biosens Bioelectron 18: 699-704.

18. Schuhmann W (2002) Amperometric enzyme biosensors based on optimized electron-transfer pathways and non-manual immobilization procedures. Rev Molecular Biotechnol 82:425-441.

19. Sarauli D, Ludwig R, Haltrich D, Gorton L, Lisdat F (2012) Investigation of the mediated electron transfer mechanism of cellobiose dehydrogenase at cytochrome c-modified gold electrodes. Bioelectrochemistry 87: 9-14.

20. Ray S, Chand S, Zhang Y, Nussbaum S, Rajeshwar K, et al. (2013) Implications of active site orientation in myoglobin for direct electron transfer and electrocatalysis based on monolayer and multilayer covalent immobilization on gold electrodes. Electr Act 99: 85-93.

21. Yewle JN, Wei Y, Puleo DA, Daunert S, Bachas LG (2012) Oriented immobilization of proteins on hydroxyapatite surface using bifunctional bisphosphonates as linkers. Biomacromolecules 13: 1742-1749.

22. Krzeminski L, Cronin S, Ndamba L, Canters GW, Aartsma TJ, et al. (2011) Orientational control over nitrite reductase on modified gold electrode and its effects on the interfacial electron transfer. J Phys Chem B 115: 12607-12614.

23. Olejnik P, Palys B, Kowalczyk A, Nowicka AM (2012) Orientation of laccase on charged surfaces. Mediatorless oxygen reduction on amino- and carboxylended ethylphenyl groups. J Phys Chem C 116: 25911-25918.

24. Ataka K, Richter B, Heberle J (2006) Orientational control of the physiologica reaction of cytochrome $c$ oxidase tethered to a gold electrode. J Phys Chem $B$ 110: $9339-9347$.

25. Sanz OG, Marques M, Pereira IA, Lacey ALD, Lubitz W, Rudiger O (2013) Orientation and function of a membrane-bound enzyme monitored by electrochemical surface-enhanced infrared adsorption spectroscopy. J Phys. Chem Lett 4: 2794-2798.

26. Tominaga J, Kamiya N, Doi S, Ichinose H, Maruyama T, et al. (2005) Design of a specific peptide tag that affords covalent and site-specific enzyme immobilization catalyzed by microbial transglutaminase. Biomacromolecules 6: 2299-2304. 
Citation: Koto A, Taniya S, Sakamoto H, Satomura T, Sakuraba H, et al. (2014) Efficient Direct Electron Transfer for a Highly Oriented PQQ-GDH Immobilized Electrode for Bioanode. J Biosens Bioelectron 5: 148. doi: 10.4172/2155-6210.1000148

27. Gao Y, Kyratzis (2008) Covalent immobilization of proteins on carbon nanotubes using the cross-linker 1-ethyl-3-(3-dimethylaminopropyl)carbodiimide--a critical assessment. Bioconjug Chem 19: 1945-1950.

28. Zheng H, Hirose Y, Kimura T, Suye S, Hori T, et al. (2006) L-Proline sensor based on layer-by-layer immobilization of thermostable dye-linked L-proline dehydrogenase and polymerized mediator. Sci Tech Adv Mater 7: 243-248.

29. Feng X, Cumurcu A, Sui X, Song J, Hempenius MA, et al. (2013) Covalent layer-by-layer assembly of redox-active polymer multilayers. Langmuir 29 . 7257-7265.

30. Zheng H, Okada H, Nojima S, Suye S, Hori T (2004) Layer-by-layer assembly of enzymes and polymerized mediator on electrode surface by electrostatic adsorption. Sci. Tech. Adv. Mater. 5: 371-376.

31. Machczynski MC, Kuhl KP, McGuirl MA (2007) Modulation of the electrochemical behavior of tyrosyl radicals by the electrode surface. Anal Biochem 362: 89-97.

32. E Ferapontova E, Gorton L (2005) Direct electrochemistry of heme multicofactor-containing enzymes on alkanethiol-modified gold electrodes. Bioelectrochemistry 66: 55-63.

33. Jeuken LJ, Connell SD, Nurnabi M, O'Reilly J, Henderson PJ, et al. (2005) Direct electrochemical interaction between a modified gold electrode and a bacterial membrane extract. Langmuir 21: 1481-1488.

34. Kim YP, Park SJ, Lee D, Kim HS (2012) Electrochemical glucose biosensor by electrostatic binding of PQQ-glucose dehydrogenase onto self-assembled monolayers on gold. J App Electrochem 42: 383-390.
35. Sakuraba H, Yokono K, Yoneda K, Watanabe A, Asada Y, et al. (2010) Catalytic properties and crystal structure of quinoprotein aldose sugar dehydrogenase from hyperthermophilic archaeon Pyrobaculum aerophilum. Arch Biochem Biophys 502: 81-88.

36. Yuhashi N, Tomiyama M, Okuda J, Igarashi S, Ikebukuro K, et al. (2005) Development of a novel glucose enzyme fuel cell system employing protein engineered PQQ glucose dehydrogenase. Biosens Bioelectron 20: 2145-2150.

37. Durand F, Stines-Chaumeil C, Flexer V, André I, Mano N (2010) Designing a highly active soluble PQQ-glucose dehydrogenase for efficient glucose biosensors and biofuel cells. Biochem Biophys Res Commun 402: 750-754.

38. Flexer V, Durand F, Tsujimura S, Mano N (2011) Efficient direct electron transfer of PQQ-glucose dehydrogenase on carbon cryogel electrodes at neutral pH. Anal Chem 83: 5721-5727.

39. Campbell WH, Henig J, Plumere N (2013) Affinity binding via Zinc (II) for controlled orientation and electrochemistry of histidine-tagged nitrate reductase in self- assembled monolayers. Bioelectrochemistry 93: 46-50.

40. Abad JM, Mertens SF, Pita M, Fernández VM, Schiffrin DJ (2005) Functionalization of thioctic acid-capped gold nanoparticles for specific immobilization of histidine-tagged proteins. J Am Chem Soc 127: 5689-5694.

41. Hu CY, Chang YJ, Yin LT, Tsao CY, Chang CH (2005) Optical design of nickelcoated protein chips using Taguchi approach. Sens and Actuat B 108: 665-670. 